\title{
Regional-scale inventory of periglacial moving landforms connected to the torrential network system
}

\author{
Mario Kummert and Reynald Delaloye \\ Department of Geosciences/Geography, University of Fribourg, Fribourg, 1700, Switzerland \\ Correspondence: Mario Kummert (mario.kummert@unifr.ch)
}

Received: 19 July 2018 - Revised: 30 November 2018 - Accepted: 3 December 2018 - Published: 14 December 2018

\begin{abstract}
When connected to torrential channels, periglacial moving landforms (including rock glaciers, push moraines and high-altitude landsliding masses) may constitute important active sediment sources for gravitational and torrential transfer processes such as debris flows. However, still very little is known about the location and the number of such types of sedimentary connection in given regions, as well as about the typical sediment transfer rates that can be expected. Therefore, this contribution aims at (i) describing a new methodology developed to identify and characterize moving landforms connected to the torrential network system at a regional scale and (ii) presenting the results yielded from the application of this method in a $2000 \mathrm{~km}^{2}$ region in the southwestern Swiss Alps. The developed approach is based on the analysis of simple data such as a high-resolution digital elevation model (DEM), time series of aerial images and a slope movement inventory. The approach allowed both the fast identification of moving landforms connected to torrential channels and the estimation of annual sediment transfer rates for these inventoried landforms. In the study region, results showed that such types of sedimentary connection appeared to be rather rare. Results also showed that most connected moving landforms were characterized by relatively low sediment transfer rates $\left(<500 \mathrm{~m}^{3} \mathrm{yr}^{-1}\right)$ but several sites were identified as transferring large amounts of sediment into the torrents $\left(>1000 \mathrm{~m}^{3} \mathrm{yr}^{-1}\right)$. As sediment transfer rates depend on the kinematical behavior of the landforms, values calculated may change in regard to the evolution of the surface velocities, which are currently generally increasing in the European Alps. When connected to torrents, periglacial moving landforms may thus represent substantial active sources of sediments for the development of debris flows and should be considered in the management of torrential catchments.
\end{abstract}

\section{Introduction}

Periglacial moving landforms, which are defined here as landforms resulting from ground motion and located in mountain permafrost environment (e.g., rock glaciers, deepseated rockslides, push moraines), can occur in the headwaters of high mountain torrential catchments. Depending on their location within the basin, they may represent substantial sources of coarse debris for the development of torrential sediment transport processes such as debris flows. The sedimentary connection or connectivity, i.e., the potential transfer of sediments from one morphological unit to the other (Bracken et al., 2015), occurs when the moving landform and the torrential channel are directly adjacent or separated by uninterrupted steep slopes where sediments can easily be eroded and guided downwards (Fryirs, 2013). As connectiv- ity describes a potential for sediments to be transported between two morphological units, it may operate at different spatial and temporal scales. For instance, connectivity can occur between adjacent sediment storages (local scale) as well as at a wider scale, typically between fluvial systems. In addition, erosion and transport of sedimentary material depend on the occurrence of geomorphic processes that can be active at different timescales (Harvey, 2002). Changes in the level of connectivity can thus occur depending on the investigated timescale. The present contribution is mainly concerned with characterizing the level of connectivity between periglacial moving landforms and torrential channels at the scale of a few decades.

Previous studies conducted on rock glaciers have shown that the erosion processes and rates occurring at the margins 
of periglacial slope movements depend, among other factors, on the ground motion rates (Kummert et al., 2018; Kummert and Delaloye, 2018). When a given moving landform is connected to a torrential channel, its movement is directed towards the torrent and the sediment transfer activity linking the two morphological units can be considered gradual in time. This (almost) continuous sediment transfer activity thus guarantees a certain level of sediment availability for debris flows and represents valuable information for the management of concerned torrents. In addition, permafrost creep rate depends - at least on interannual and decennial bases - on temperature (Kääb et al., 2007; Delaloye et al., 2008; Bodin et al., 2009; Kellerer-Pirklbauer and Kaufmann, 2012). In response to the recent climatically driven increase in ground temperatures, a very substantial acceleration of rock glaciers and other permafrost creeping landforms has been reported, especially from the European Alps (e.g., Roer et al., 2005; Kaufmann et al., 2007; Ikeda et al., 2008; PERMOS, 2016). The sediment transfer rate of rock glaciers is hence being modified and will continue - at least up to a certain point in response to the ongoing air temperature increase. With the generally high surface velocities, sediment availability is expected to increase in the headwaters of torrential catchments and potentially impact the frequency and magnitude of torrential transfer processes.

The magnitude of a debris flow event refers to its flow depth, travel distance and affected areas, while the frequency is related to the recurrence interval of such an event (Zimmermann et al., 1997; D'Agostino and Marchi, 2001). Their assessment represents a basic step towards the determination of torrential hazards in a given catchment. Debris flow magnitude and frequency are close functions of both frequency of occurrence of specific hydroclimatic events capable of initiating the torrential transport (e.g., Rickenmann, 1999) and terrain variables including sediment availability on hillslopes and channels (e.g., Bovis and Jakob, 1999). Therefore, an increase in the sediment transfer rate between periglacial moving landforms and torrents is likely to lead to higher debris flow magnitude and/or frequency in the concerned catchments as it continuously enhances the volume of available sediments (Kummert and Delaloye, 2018). If the evidence of such an increase in the frequency and magnitude of debris flows starting from glacier and permafrost areas has not been highlighted yet at a large temporal scale (e.g., Rebetez et al., 1997; Jomelli et al., 2007; Sattler et al., 2011), the potential effect of slope movement acceleration on channel recharge rates might be significant in specific catchments.

There is thus a need to better identify and characterize the cases of sedimentary connection between moving landforms located in periglacial environments and torrential channels. Recently, several studies applied quantitative approaches to determine connectivity within mountainous catchments. For instance, Heckmann and Schwanghart (2013) presented a network analysis approach to quantify connectivity using numerical models to simulate rock falls, debris flows and fluvial transfer processes. In another example, Cavalli et al. (2013) proposed a methodology based on the geomorphometric analysis of a high-resolution digital elevation model (DEM) to compute values of connectivity for individual pixels in relation to a specified target (i.e., the catchment outlet or the main channel). These different approaches can be considered only semiquantitative as they give relative values of connectivity and do not allow characterization of the presence and absence of sediment connectivity between morphological units. In addition, none of these studies look at the very local-scale connections such as the one that can exist between moving landforms and torrential channels.

Hence, if such types of sedimentary connection have already been identified for some specific sites in the European Alps (e.g., Lugon and Stoffel, 2010; Delaloye et al., 2013; Kummert et al., 2018), very little information exists at the regional scale, for instance about (i) the number and (ii) the location of torrential catchments characterized by the presence of moving landforms connected to channels, but also (iii) the rates at which sediments are being transferred. To address these questions, a methodology aiming at inventorying the cases of moving landforms connected to the torrential network system at the regional scale has been developed. The overall goal of the method is to provide a map in which all the catchments concerned by the presence of moving landforms connected to torrential channels are identified and associated with estimations of the sediment transfer rate. Such a map would then constitute an indicative layer of information pointing out sites where more detailed site-specific investigations could potentially be launched if judged necessary. It is important to note that the method differentiates itself from debris flow hazard assessments by investigating only the presence and the activity of periglacial moving landforms without considering other sediment sources. In addition, the developed methodology was designed to be easily applicable at a regional scale without needing important and timeconsuming preparatory data gathering or processing. After presenting the study region, the datasets and the methodology, this paper reports the results yielded from its application in a test study region in the southwestern Swiss Alps.

\section{Context and settings}

\subsection{Study objects}

In the present contribution, three main types of periglacial moving landforms are considered, namely rock glaciers, push moraines and high-altitude deep-seated rockslides. In reality, other types of landforms resulting from ground movements can usually be observed in periglacial mountain environments, as is for instance the case of solifluction lobes or debris-covered ice bodies, and may potentially participate to transfer sediments towards the torrential network system. Occurring only at shallow depth (maximally ca. $1 \mathrm{~m}$, e.g., Matsuoka, 2001), solifluction is however expected to 
have a limited impact in terms of transported volumes. Movements related to debris-covered massive-ice bodies are generally characterized by a dominating vertical component due to ice melt, especially during summer periods (e.g., Bosson and Lambiel, 2016). Even though their content in rock debris can be important, their dynamic renders them weakly efficient in transporting sediments downward (Shroder et al., 2000; Benn et al., 2003). Conversely, rock glaciers, deep-seated rockslides and push moraines represent often important volumes of transported sediment and may contribute to feed torrents with rock debris. Rock glaciers consist of tongueshaped or lobate landforms composed by a mix of variously sized rock particles, which, under a few meters of nonpermanently frozen rock debris (i.e., the active layer, Williams and Smith, 1989), are cemented by interstitial ice (Barsch, 1992). The deformation of the interstitial ice explains the downslope movement of a rock glacier (i.e., the rock glacier creep; e.g., Haeberli et al., 2006) and concentrates mostly in one main shear horizon (e.g., Arenson et al., 2002; Buchli et al., 2012), in some cases in several of them (e.g., Kummert et al., 2018). Push moraines also consist of frozen sediments moving through permafrost creep (Haeberli, 1985; Delaloye, 2004). They are thus often comparable to rock glaciers in terms of size, surface morphology and internal structure. Push moraines are always found in the periphery of glacier forefields and their movement results mainly from the disturbance caused by a former glacier advance. For that reason, their motion is generally oriented towards the center of the area formerly occupied by the glacier (back-creeping). Finally, deep-seated landsliding masses can often be observed on high mountain hillslopes located in permafrost environments. They generally correspond to large rockslides affecting important volumes and surfaces. Their movement is likely to be related to deep slide planes (up to $>100 \mathrm{~m}$ ) and reach typical velocities of a few centimeters to several tens of centimeters per year. Their internal content is vastly unknown but is probably composed of fractured bedrock with a surface usually composed by an open-work structure of big dislocated boulders, which are being transported downward by the slow motion of the whole landform. Recent studies focusing on their dynamic seem to indicate that their kinematical behaviors share similarities with the ones of rock glaciers, indicating that a part of their total movement may be related to permafrost creep (e.g., Delaloye et al., unpublished data). In addition, studies conducted on low-altitude landslides (e.g., Korup, 2005; Schwab et al., 2008) showed that such types of deep-seated moving landforms may represent significant sediment sources for torrential as well as lowland river basins. For these reasons, it is expected that high-altitude deep-seated rockslides may participate in transferring sediments downwards towards torrents.

\subsection{Study region}

The study region is located in the southwest of Switzerland and is entirely comprised in the Valais canton. It encompasses nine lateral valleys (see the names in Fig. 1) generally oriented on a south-north axis, with rivers flowing towards the north into the Rhône River (Fig. 1). The western half of the Entremont valley was excluded from the study region because it is not covered by the slope movement inventory used as input data. The overall study region is about $2000 \mathrm{~km}^{2}, 54 \%$ located above $2500 \mathrm{~m}$ a.s.l., which can be considered the local approximation for the lower limit of discontinuous permafrost (Delaloye and Morand, 1997; Lambiel and Reynard, 2003). Higher altitudes are commonly found in the southern halves of the valleys and are generally characterized by the presence of glaciated areas (typically above $3000 \mathrm{ma.s.1}$.) and steep rock walls leading upwards to ridges constituting the drainage divides among the valleys. The highest point of the study region is reached at $4634 \mathrm{ma}$ a.s.l. at the summit of the Pointe Dufour (Monte Rosa) in the southeastern limit of the Mattertal valley. The flanks of each valley correspond to relatively steep slopes divided into numerous torrential systems linking high-altitude glacial and periglacial areas with the respective bottom of the valleys (Fig. 1). The study area constitutes the common focus of research projects conducted at the Unit of Geography of the University of Fribourg for several years and therefore a large number of data exist, especially concerning the detection and the monitoring of slope instabilities such as rock glaciers, rockslides and push moraines. For instance, ongoing projects using dGNSS (differential Global Navigation Satellite System) or TLS (terrestrial laser scanning) surveys at specific site locations were helpful for the validation of the developed method (Delaloye et al., 2010, 2013; Kummert and Delaloye, 2015, 2018; PERMOS, 2016).

\subsection{Data}

The developed methodology is based on the exploitation of various available datasets: (i) a slope movement inventory, (ii) a DEM and (iii) series of aerial images covering the entire study region.

\subsubsection{Slope movement inventory}

A slope movement inventory based on the analysis of DInSAR (differential synthetic aperture radar interferometry) scenes mainly from the ERS $1 \& 2$ satellites (European Radar Satellites 1 and 2 , half wavelength $=2.8 \mathrm{~cm}$ ) and dating back to the 1990s (1993-2000) was used to localize slope movements present in the study region. This inventory recorded all the areas located between the upper limit of the forest and the glaciated areas and where ground movement was detected on DInSAR scenes. More details about the inventory method and results can be found in Delaloye et al. (2007a, b), 


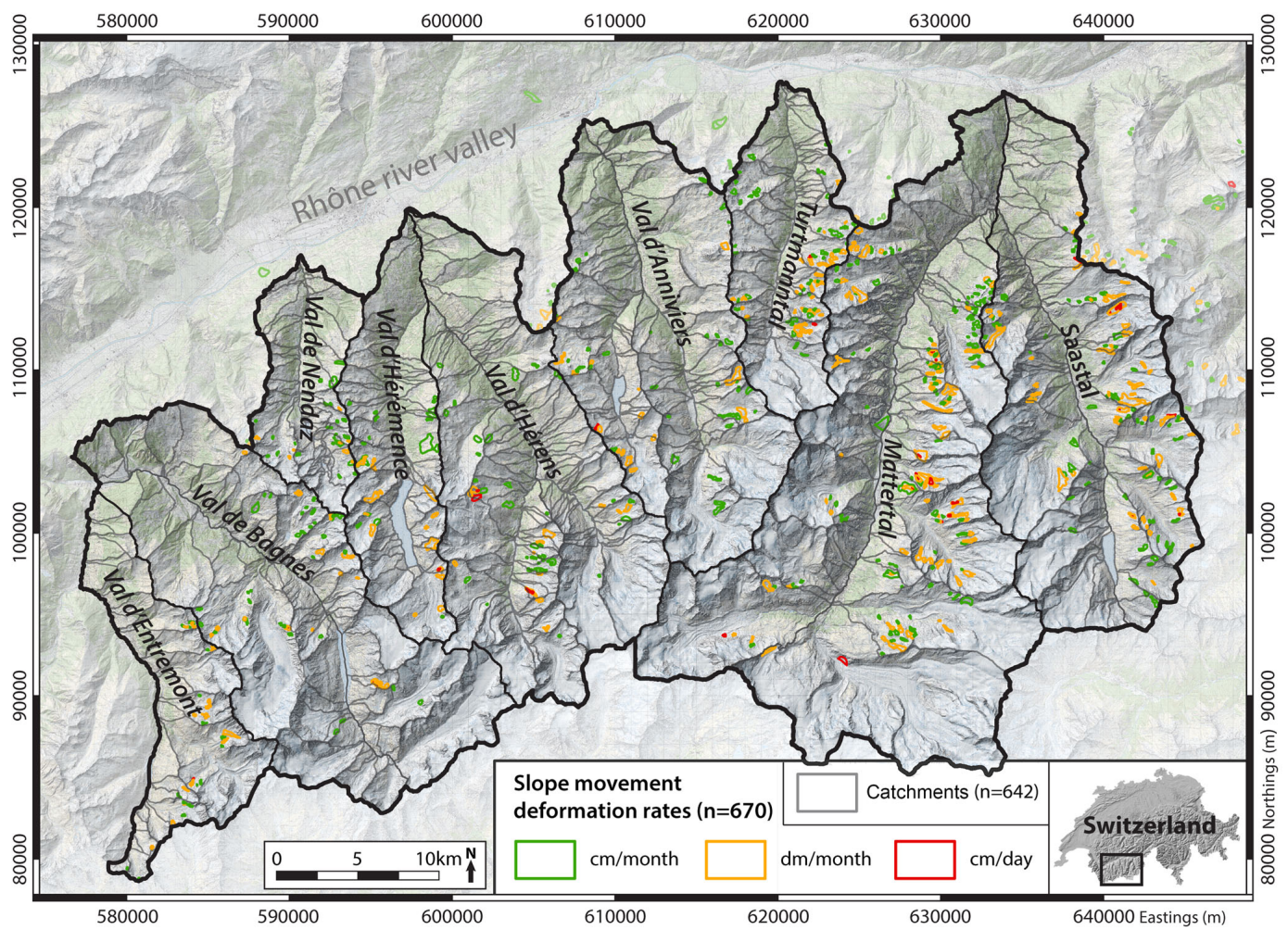

Figure 1. Map of the study region, with the delimitation of the nine lateral valleys. The delimited catchments and interfluves are represented and DInSAR polygons (color) representing slope movements (rock glaciers, push moraines and deep-seated rockslides) are included. Base map from @Swisstopo.

Lambiel et al. (2008) and Barboux et al. (2014). The final inventory takes the form of a shapefile in which each moving area detected on DInSAR interferograms is represented by a polygon and linked to an attribute table in which information about the localization, landform type and velocity rate is stored. The contours of the DInSAR polygons are indicative, as they delimitate areas affected by slope movement as observed from $25 \mathrm{~m}$ resolution interferograms, and therefore do not necessarily correspond to real morphological limits. In the frame of this DInSAR inventory, orthophotos were visually interpreted to attribute a landform type to each polygon (e.g., rock glacier, debris-covered glacier, push moraine, moraine, gelifluction, debris mantle and landslide) but were not used to modify the contours of the polygons in order to fit to landform boundaries. The inventory also provides orders of magnitudes for the detected movement following four main classes, depending on the time interval characterizing the DInSAR scenes on which the movement was detected (Delaloye et al., 2007b): $\mathrm{cm} \mathrm{day}^{-1}$ (coherent displacement signal for 1-day intervals), dm month ${ }^{-1}$ (decorrelated displacement signal for 35-day intervals), $\mathrm{cm} \mathrm{month}^{-1}$ (coherent signal for 35-day intervals) and $\mathrm{cm} \mathrm{yr}^{-1}$ (coherent signal for $>300$-day intervals). The DInSAR inventory gave indications about the presence of slope movements but remains non-exhaustive. Approximately $10 \%$ of the region was not covered by the interferograms due to layover and shadow effects (Barboux et al., 2014) and as a result some moving landforms might be undetected. In addition, the inventory relies on data from the 1990s and changes in ground motion activity are likely to have occurred in the past 20 years, as for instance the development of new moving zones, the deactivation of others or simply changes in the magnitude of the movements. Nevertheless, such a dataset was used here to facilitate the application of the methodology by indicating the location of most of the moving landforms present in the study area. Given the purpose of the study, only landforms that may actively transfer large amounts of rock debris downward, namely rock glaciers, deep-seated rockslides and push moraines (see Sect. 2.1.), were kept as a base inventory. Polygons representing either shallow slope movements (typically solifluction slopes) or glacier-related movements (glaciers, debris-covered glaciers and dead-ice bodies) were excluded.

\subsubsection{Digital elevation model}

A DEM of $2 \mathrm{~m}$ resolution (SwissAlti3D; @Swisstopo) was used as a base map (hillshade) as well as to calculate some required morphometric variables. The map of all catchments and interfluves segmenting each valley flank (Fig. 1) was pro- 
duced by applying basic spatial analysis tools on the DEM (flow direction and flow accumulation algorithms) and by manually defining the outlets of each torrent as the target for the flow accumulation computation. Catchments were defined as such when the drainage network converged towards one well-incised main channel leading to the valley bottom, while the word interfluve was used here for hillslope sections separating two catchments and where the drainage system mainly consisted of parallel intermittent streams.

\subsubsection{Time series of aerial images}

Series of orthorectified aerial images covering the whole region for different years between 1999 and 2015 were used both (i) qualitatively through the visual interpretation of the state and the evolution of the studied catchments and landforms and (ii) quantitatively by extracting values of surface displacements from image pairs for selected moving landforms. The orthorectification of the images was performed directly by the Swiss federal office of topography (Swisstopo) and its quality has not been assessed in the frame of the present study. Deformations or potential shifts between images from different dates are thus possible depending on the presence of shadow or on technical issues. In general, older images are characterized by a lower quality. In any case, the important number of images available (four to five depending on the location in the study region) secures usually at least one good image pair (2007-2010/2011, generally) from which the extraction of information about landform dynamics was possible.

\section{Description of the developed methodology}

Given the multiplicity of goals, the methodology was established following several steps (Fig. 2). First, the level of connectivity between moving landforms and torrential channels is assessed following two separate stages of analysis. Then, sediment transfer rates are estimated for the moving landforms identified as connected to the torrential network.

\subsection{Connectivity assessment}

The first step relies on checking whether a moving landform is connected to a torrential channel in each catchment and interfluve located in the study region. The sedimentary connection between moving landforms and torrents was assessed by evaluating the level of both structural and functional connectivity (Lexartza-Artza and Wainwright, 2009; Messenzehl et al., 2014) from the identification of visual clues on recent aerial images (2010-2012).

\subsubsection{Structural connectivity}

The structural connectivity corresponds to the physical contact between two adjacent sediment storages. In our cases, it

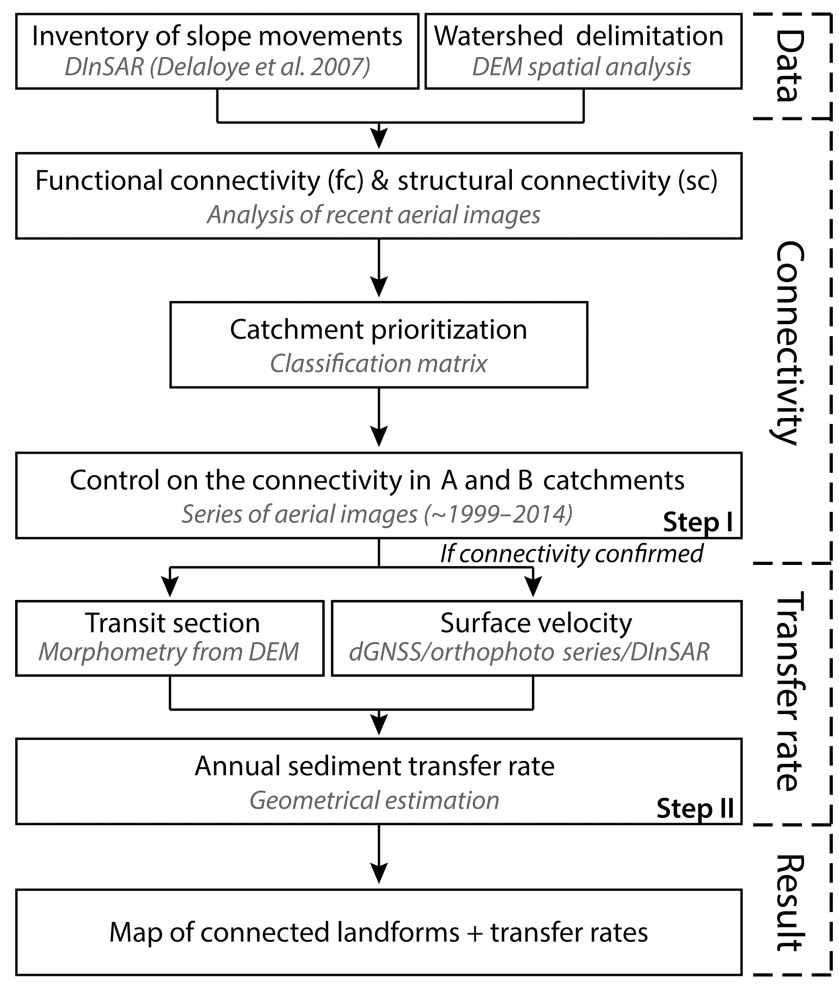

Figure 2. Systemic scheme representing the different steps of the developed methodology.

can be assessed by examining whether each polygon representing a moving landform is adjacent to a torrential channel. This proximity can be lateral or frontal, in the sense that the landform can be located alongside the channel or upslope in the continuity of the flow direction (Fig. 3).

\subsubsection{Functional connectivity}

The functional connectivity refers to the actual active sediment transport between two sediment storages or two morphological units. In the images, the functional connectivity was assessed by looking at traces of recent (2007-2012) sediment transfer activity between the moving landform and the channel, and in the channel itself (Fig. 3). For instance, the presence of fresh sedimentary material within the channel indicates an active connectivity with the main sediment sources.

\subsubsection{Classification method}

For each torrential catchment or interfluve, a score of structural and functional connectivity, respectively, is given. The score can be 0 , if the respective connectivity is apparently nonexistent, or 1 , if the visual analysis of the images indicates that there is an efficient connectivity. The score 0.5 is only given for structural connectivity when the moving landform is located near the channel but not directly adja- 

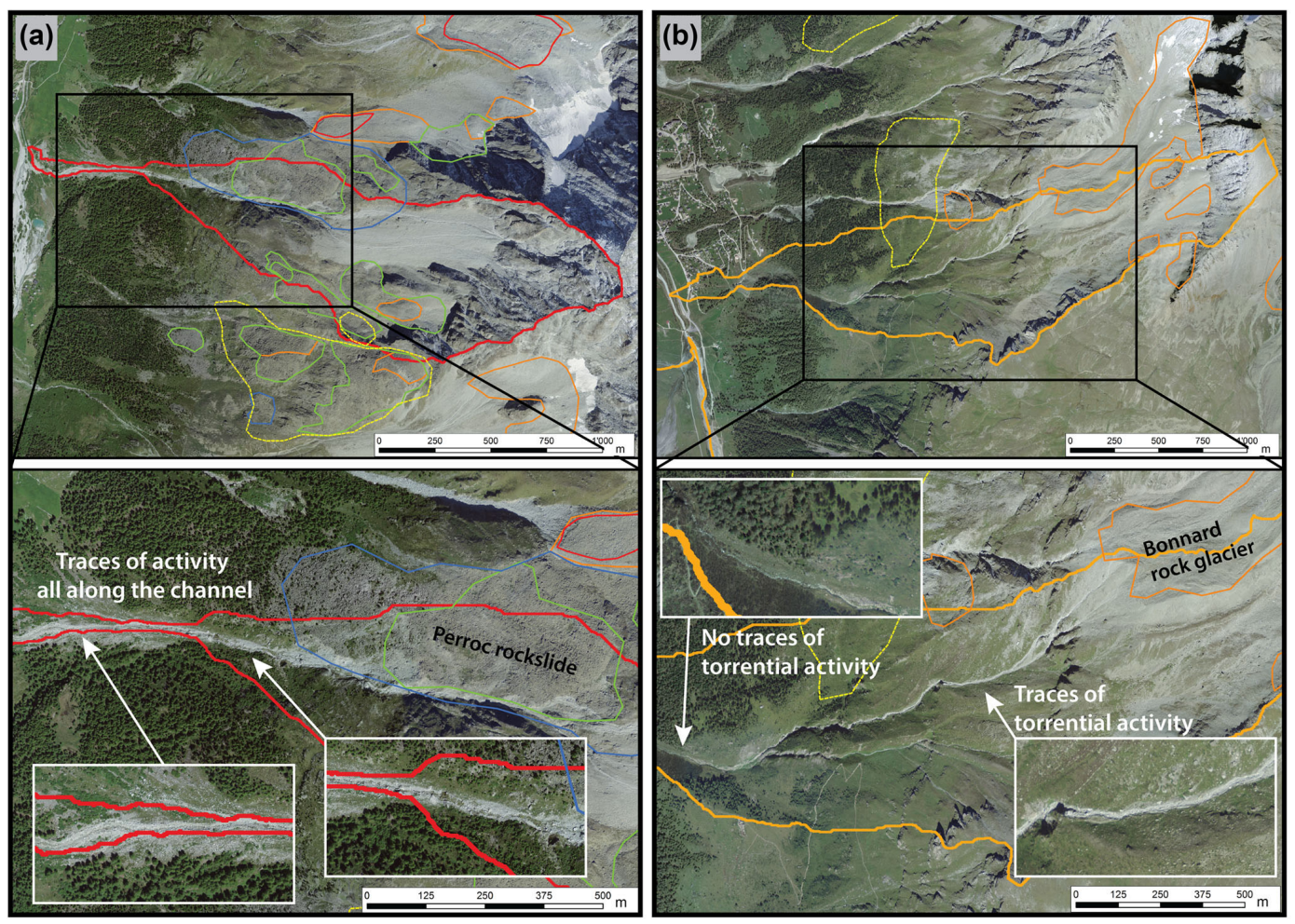

Figure 3. Examples of connection between slope movements and torrential channels. For case A (a), the Perroc rockslide is located alongside the main channel (structural connectivity $=1$ ), and traces of sediment transfer activity characterize the whole length of the channel (functional connectivity =1). For case B (b), the Bonnard rock glacier is located upslope from the head of the main channel (structural connectivity =1) but traces of sediment transfer can be seen only in the upper section of the channel, reducing the score of functional connectivity (functional connectivity $=0.5$ ). Orthoimages $@$ Swisstopo.

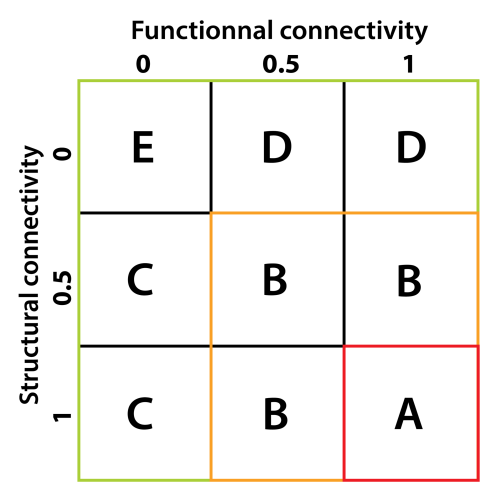

Figure 4. Matrix used to classify the catchments following the level of connectivity between slope movements and torrential channels.

cent and for functional connectivity when the traces of sediment transfer activity concern only localized sectors of the channel. The scores of connectivity are then used to classify catchments and interfluves using the matrix shown in Fig. 4. The classification procedure allows the identification of the catchments characterized by a high probability of active sediment transfer between a moving landform and a torrential channel, namely classes A and B. It aims at reducing the number of catchments in which more investigations can be undertaken. Basically, classes A and B should correspond to all catchments in which at least one moving landform is suspected to be connected to a torrential channel and where traces of recent sediment transfer activity are at least present in some segments of the channel. $\mathrm{C}$ catchments are characterized by the direct proximity between at least one moving landform and an inactive channel. $\mathrm{C}$ catchments typically encompasses torrents characterized by important flat channel segments close to which some moving landforms may develop. D catchments correspond to active torrents exhibiting recent traces of sediment transfer activity but where no connected moving landform is identified in the vicinity of the channel network. Finally, catchments classified as E show no traces of sediment transfer activity in the channels and are characterized by the absence of moving landforms in direct proximity to the torrential network system. The described classification method is based on the rapid interpretation of visual clues on the aerial images, and the connectivity assessment is still very basic. In catchments and interfluves classified as A or B, a more "in-depth" check is thus performed for each moving landform identified as potentially connected to a torrential channel. 


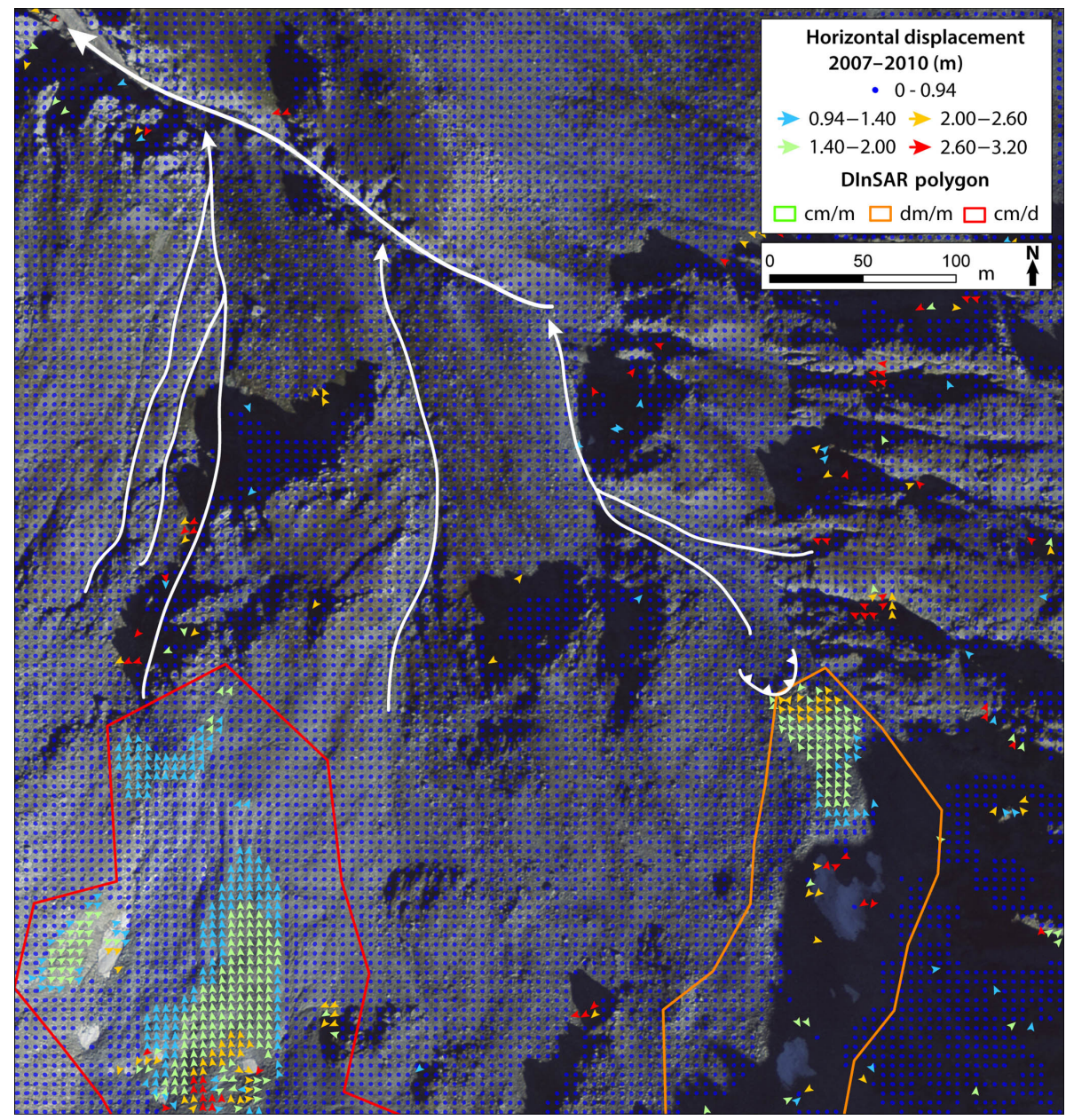

Figure 5. Two moving landforms located in the Torrent de Perche catchment in Val d'Entremont. The horizontal displacements calculated by image correlation are represented by the arrows and dots. From this map, moving landforms can be considered both connected, as detected displacements are close to active channels, and directed towards it. Furthermore, this example nicely illustrates the sometimes inaccurate delimitation of DInSAR polygons compared to real geomorphological landforms and activity. Orthoimage @Swisstopo.

\subsubsection{Detailed connectivity assessment}

The proximity between a moving landform and the main channel does not guarantee sediment transfer between the two morphological units. The slope movement could be parallel or divergent regarding the main runoff flow direction, even though the landform is identified as directly adjacent to the main channel. In such a configuration the moving landform does not actively contribute to transporting sediments towards the channel and thus does not correspond to the scope of the present research. As the DInSAR polygons were delimited based on identified moving areas and not on the morphology of the terrain, their boundaries may not always follow the outer limit of real geomorphological objects. In addition, the resolution of the interferograms used to identify moving features is relatively coarse $(25 \mathrm{~m})$ and does not allow precise contours to be drawn (see Fig. 5). Finally, traces of sediment transfer observed in channels do not necessar- ily indicate that an active sediment transfer from the moving landform exists, as it could originate from the presence of other sediment sources in the catchment. For these reasons, the occurrence of actual sediment transfer towards torrents is systematically verified in catchments and interfluves classified as A or B. The main elements that are checked are the movement flow field, the presence of previously unidentified topographical buffers between the landforms and the channels, and the existence of recent traces of sediment transfer activity between the margins of the moving landforms and the torrential channels.

Most of these elements can be checked by conducting a more detailed geomorphological analysis of the time series of orthoimages. For instance, the direction of the movement and its precise location within the DInSAR polygon can be assessed by simply displaying one image after the other and checking whether the blocks on the surface of the landforms move in the direction of the channel. In the cases of unclear 


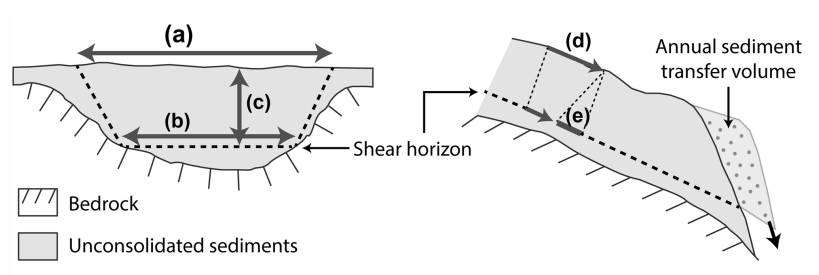

$\begin{array}{llll}\text { (a) Surface width }(m) & \text { (b) Base width }(m) & \text { (c) Thickness }(m) & \left.\text { (d) Surface velocity (m year }{ }^{-1}\right)\end{array}$ (e) Velocity decrease at the shear horizon vs the surface (\%)

Annual sediment transfer $=((a+b) . c .(d+d .(1-e))) / 4$

Figure 6. Schematic view of a rock glacier with the different dimensions (a-e) used to estimate the annual sediment transfer rate. In this method, it is assumed that all the sediments brought forward by the rock glacier advance are mobilized and transferred towards the gully (adapted from Kummert and Delaloye, 2018).

flow direction, an image correlation algorithm can be used to produce displacement vectors, which more accurately indicate the main movement flux (Fig. 5). In the present study, the SAGA GIS software, which includes an image correlation tool, was successfully tested to obtain displacement vectors based on pairs of images at several sites. However, the displacement flow fields were usually relatively easy to identify by simple visual analysis of images series, and the computation of displacement vectors was not required for most of the cases. Based on these more detailed observations, the previous classification can be refined and the confidence in the connectivity assessment is increased. As a result, an inventory of all catchments and interfluves in which at least one moving landform contributes to transfer sediment towards the torrential network can be produced.

\subsection{Estimation of sediment transfer rates}

Once identified, the approximate sediment transfer that characterizes moving landforms connected to the torrential network can be assessed using a simple approach, based on previous work for instance by Delaloye et al. (unpublished data). This estimation method is based on the hypothesis that the sediment transfer occurs through a constrained transit section, namely the front of the moving landform. If we assume that the position of the front does not change in time, as observed for several cases in the study region (Delaloye et al., unpublished data; Kummert et al., 2018), the annual sediment transfer rate between a moving landform and the torrential network corresponds to the volume of sediment that passes through this transit section each year and can be assessed roughly by multiplying the surface of the transit section by the annual displacement rate of the landform.

\subsubsection{Transit section}

The transit section, i.e., the contact area between the moving landform unit and the channel, was visually identified on the aerial images. It corresponds in most cases to a well-defined front located at the lowermost end of the moving landform and whose dimensions can be measured on the DEM in a GIS software. The width can usually be estimated as the distance between the lateral limits of the frontal area, while the height could be approximatively assessed by measuring the elevation difference between the mean altitude of the front line (measured on the DEM for several points) and the mean altitude of the foot of the front (e.g., Humlum, 2000; GärtnerRoer and Nyenhuis, 2010). In cases in which the transit section does not correspond to a well-defined front, typically for deep-seated rockslides, other morphological clues such as changes of slope angle or the presence of bedrock outcrops could be taken as indicators of the lower limit of the transit section. The estimated thickness value is generally more prone to errors than the width as the lower limit of the movement is often more difficult to identify on aerial images than the width. Very often, the main shear horizon is located above the foot of the front, but it can also be located well below in the case of deep-seated mass movements. We, however, assume that the errors in defining this lower limit are in most cases relatively low (maximally a few meters) and do not substantially impact the surface values obtained for the transit sections, which often reach several thousand square meters. The area for the transit zone is obtained by multiplying the section width with the depth of the motion. As most of the periglacial moving landforms connected to torrential channels are flowing downward in topographical depressions that represent the upslope continuations of the main channels, the widths of the moving sections are often shorter at depth than at the surface (Fig. 6; e.g., Kummert and Delaloye, 2018). Therefore, the measured surface width values are reduced by $20 \%$, which corresponds to a reduction of about $40 \%$ of the width at the shear horizon, to avoid overestimations of the transit sections' size.

\subsubsection{Surface velocity}

Horizontal surface displacement values can be obtained from the tracking of moving features on the surface of the landforms from pairs of relatively recent aerial images (2007 and 2010,2011 or 2012 depending on the landforms). As it is mostly the velocity characterization in the terminal part of the landform that is relevant for the erosion of the fronts (Kummert and Delaloye, 2018), displacement values were calculated for (at least) four easily identifiable boulders located as near as possible to the front lines. The results were then averaged and divided by the number of years covered by the image pairs to obtain a mean horizontal surface velocity rate for each moving landform. These values were then confronted to classes of displacement rates obtained from an update of the DInSAR inventory performed with new interferograms covering a period spanning from 2008 to 2012 (Barboux et al., 2014). In case of significant differences in magnitude detected between the two datasets, velocity val- 


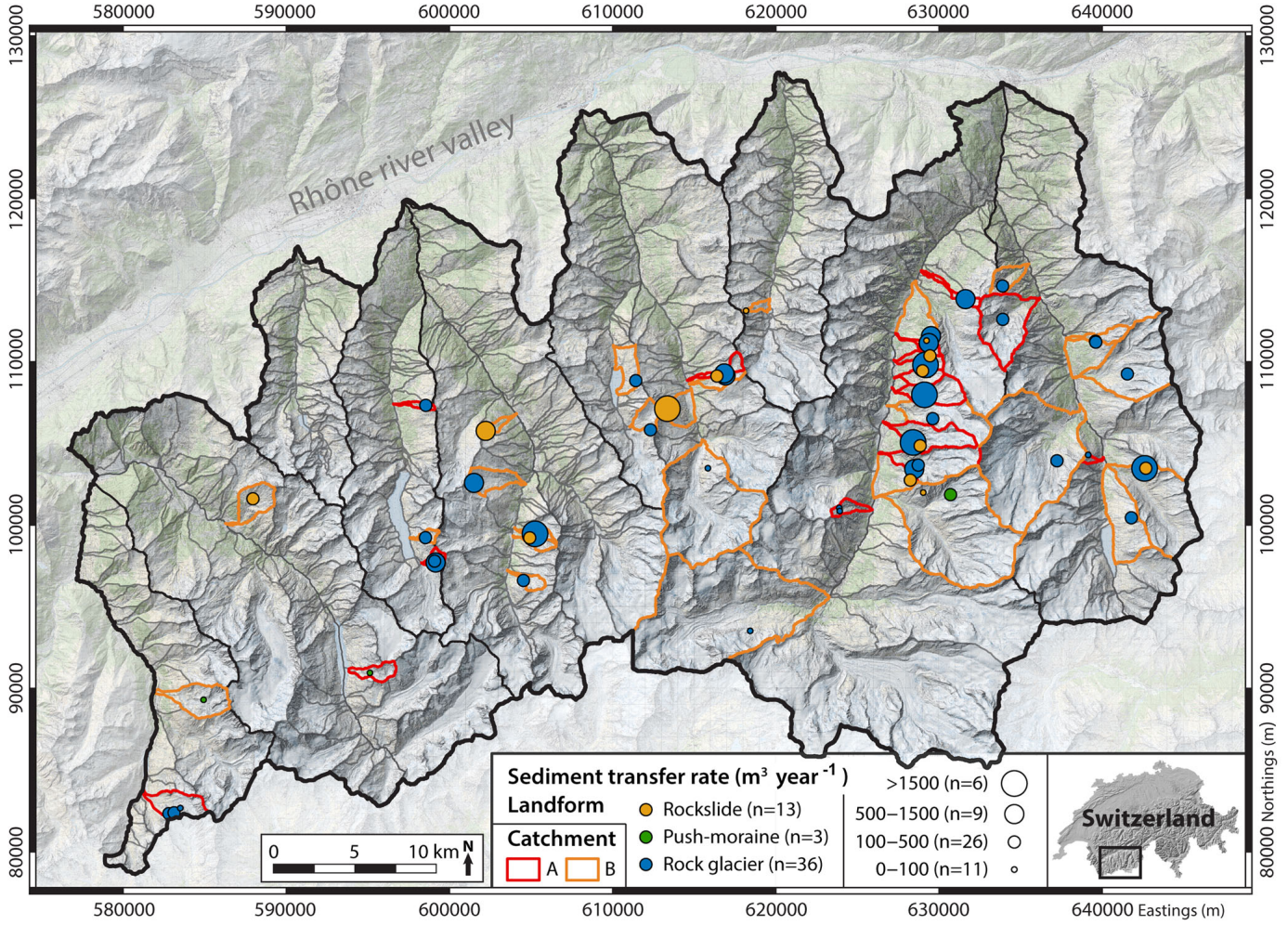

Figure 7. Main result map showing the identified catchments and connected landforms, the circle size indicating the class of sediment transfer rate $\left(\mathrm{m}^{3} \mathrm{yr}^{-1}\right)$ and the color referring to the landform type. Base map from @Swisstopo.

ues estimated from the image pairs could be double-checked for potential errors. In some rare cases, time series of geodetic surveys (dGNSS) were available and could validate values obtained from the analysis of the pairs of aerial images. For each identified connected moving landform, the 2-D surface velocity estimated from aerial images was reduced by a $25 \%$ factor in order to take into account the velocity decrease with depth. The chosen value of $25 \%$ is based on the assumption that the displacement rate at the shear horizon is approximately half the one measured at the surface. Actually, data from boreholes have shown that the deformation rates at the shear horizon can span between $50 \%$ and $97 \%$ of the surface velocity (Arenson et al., 2002; Buchli et al., 2012). Applying such a $25 \%$ reduction appeared thus to be conservative and allowed us to avoid overestimations in the calculation of the mean displacement rates.

\subsubsection{Transfer rate estimation}

The annual sediment transfer rate can be roughly estimated by multiplying the dimensions of the transit section and the value of mean annual velocity (Fig. 6). The yielded results correspond to an estimation of the amount of material crossing the frontal area each year. The developed approach does not take into account the porosity of the material, mostly because such information is not available. It is simply assumed that the difference in porosity between debris encompassed in the moving landform body and slope deposits reposing in the channel is relatively small and their impact can be neglected. In addition, the presence of interstitial ground ice possibly occupying a larger volume than the porosity (supersaturation) has to be expected in these periglacial moving landforms. The melt of this "ice excess" could induce a variation in the volume occupied by the same sediments within the moving landform and in the torrents but was also neglected as the role it may play is still vastly unknown and might be highly variable among sites depending on the ice content.

\section{Results}

\subsection{Connectivity assessment}

Out of 642 delimited catchments $(n=323)$ and interfluves $(n=319)$, the detailed connectivity assessment applied in the study region allowed the identification of 42 catchments and interfluves classified as A or B (6.5\% of the total) and in which at least one moving landform is connected to the torrential network system (Fig. 7). In terms of spatial distribution, $52 \%$ of the inventoried catchments are located in only two of the investigated valleys (Mattertal and Saastal), while $31 \%$ are located in the Mattertal only. The vast majority of these catchments and interfluves develop on west- 


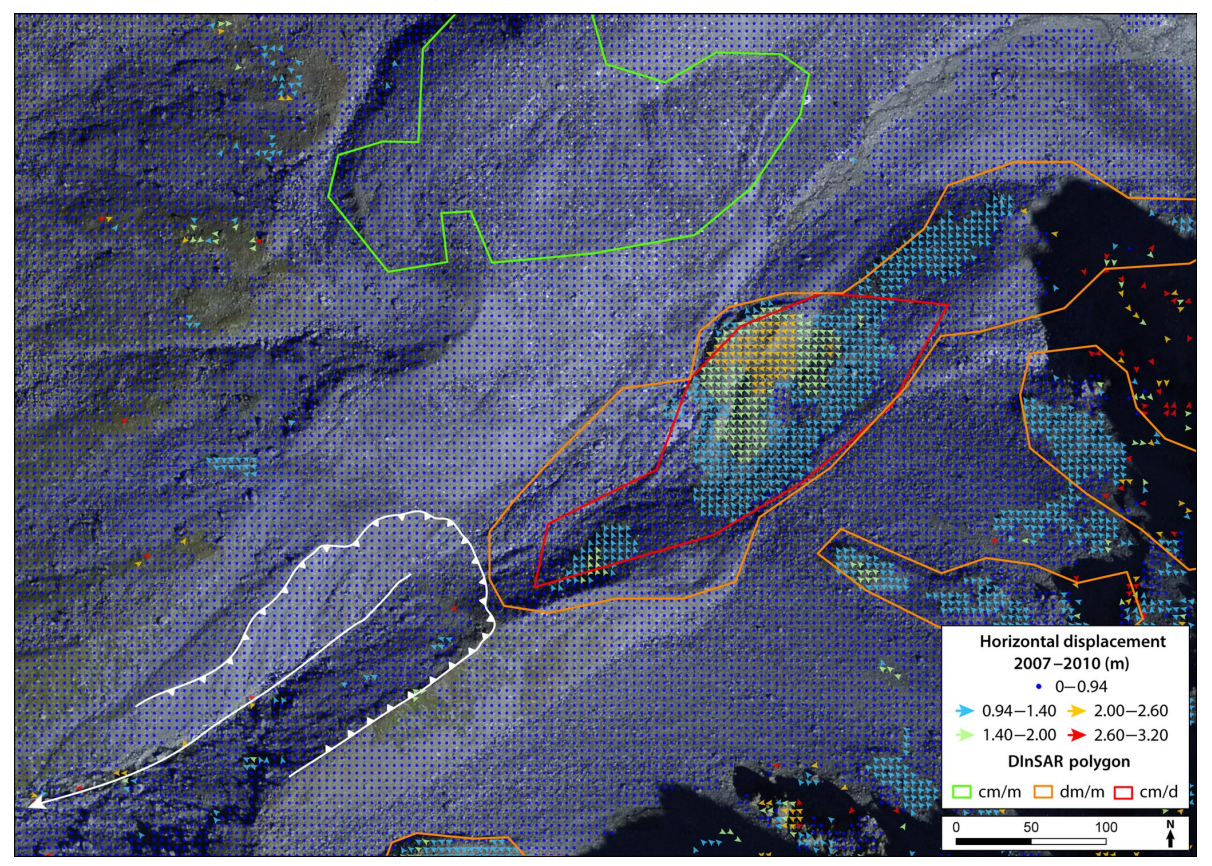

Figure 8. Example of a moving landform directly adjacent to the main torrential channel but whose movement is oriented perpendicular to the main flow direction (indicated by white arrow). In this case, the slope movement was identified as connected in the first assessment and was ruled out following the more in-depth connectivity check. Orthoimage @Swisstopo.

oriented slopes, probably in relation to the overall orientation of the local geological ensembles, which generally dip to the southeast, favoring the establishment of both gentle southeast-oriented and steep northwest-oriented slopes, the latter favoring direct sediment connectivity. Amongst the 42 catchments, 52 moving landforms have been identified as connected to the torrents ( $\sim 8 \%$ of all slope movements detected with InSAR). The large majority are rock glaciers (69\%), followed by deep-seated rockslides $(25 \%)$ and push moraines $(6 \%)$. The overall number of connected landforms has been reduced by $28 \%$ from the original connectivity assessment by applying the more in-depth analysis of movement flux direction (72 moving landforms before and 52 after). The moving landforms that have been reclassified as unconnected during the second in-depth connectivity assessment were essentially ruled out due to their inadequate flux direction or due to clear topographic buffering (e.g., flat terrain). They consisted for instance of push moraines located close to channels in the outer edges of Little Ice Age (LIA) glacier forefields but back-creeping towards the center of the forefield (Fig. 8). In addition, the spatial extent of some DInSAR polygons was too large, giving the misleading impression that the moving landforms were directly adjacent to the torrential channel while the real moving parts were located at a sufficient distance to be disconnected for instance by the presence of flat areas between them and the channel (Fig. 8). Finally, several deep-seated rockslides were classified as not connected as no clear sediment transit section could be identified and defined. In such a case, the movement usually af- fected entire hillslopes but no traces of loose sediment transfer could be specifically observed between the rockslides and the torrents.

\subsection{Sediment transfer rates}

The estimated sediment transfer rates calculated for each connected landform are mapped in Fig. 7 and can be found in more detail in the Supplement. A relatively wide spectrum of values was obtained, ranging roughly from $6500 \mathrm{~m}^{3} \mathrm{yr}^{-1}$ to almost zero. The majority $(71 \%)$ of moving landforms was characterized by moderate transfer rates, typically lower than $500 \mathrm{~m}^{3} \mathrm{yr}^{-1}$, and only nine exceeded $1000 \mathrm{~m}^{3} \mathrm{yr}^{-1}$, with a median sediment transfer rate of $238 \mathrm{~m}^{3} \mathrm{yr}^{-1}$. In terms of landform type, mostly rock glaciers were associated with high sediment transfer rates, with only two rockslides and no push moraines yielding more than $500 \mathrm{~m}^{3} \mathrm{yr}^{-1}$. In general, rock glaciers were characterized by higher flow rates but smaller transit sections than deep-seated rockslides, while push moraines commonly displayed very small transit sections. The spatial distribution shows a strong concentration of moving landforms characterized by high sediment transfer rates in the west-oriented side of the Mattertal. Aside from that specific case, no definite spatial patterns can be observed. 


\section{Discussion}

The application of the developed inventory method in the study region showed that the cases of sedimentary connectivity between periglacial moving landforms and torrential channels is quite uncommon but may lead in some cases to substantial sediment inputs into torrents (up to several thousand cubic meters). The methodology has proven to be relatively simple and allows a fast survey over a relatively large study area. It seems well suited to regional studies as far as good input datasets are available for the whole area. It was also designed to be relatively easy to update, for instance if new information about the displacement rates of moving landforms becomes available. Sediment transfer rates can be regularly recalculated with more recent data, which makes sense given the temporal variability in permafrost creep rates and their dependency on climatic conditions. The application of the method can thus quickly provide a map of connected moving landforms with respect to their sediment transfer activity based on estimated values that can easily be updated. The methodology is however based on several steps for which uncertainties and limitations exist. In general, the aim of proposing a relatively easily applied approach required simplifications from which several questions can arise.

\subsection{Subjectivity of the approach}

The applied methodology relies strongly on the visual analysis of aerial images and is dependent on the interpretation of the observer. The visual indicators for the connectivity assessment are clearly defined in order to lower the subjectivity but in some cases, the choice between two scores of connectivity can be difficult. To overcome this problem, the determination of the connectivity between moving landforms and torrential channels was performed by two users separately for about half of the study region, i.e., in the valleys of Entremont, Bagnes, Nendaz, Hérémence and Hérens. As the same results have been obtained by both users, we can argue that subjectivity has a limited impact, as long as the users have a certain level of skills and experience with such types of geomorphological analysis. Another option to overcome the subjectivity is the application of automatic approaches to infer connectivity. As mentioned, recent studies proposed semiquantitative methods based mostly on the geomorphometric analysis of DEMs (Cavalli et al., 2013) and numerical modeling of transfer processes (Heckmann and Schwanghart, 2013) to map potential connectivity. These approaches are interesting because they spatially constrain areas where the connection with the main fluvial network is most probable. However, important limitations characterizing these methods can be pointed out and render them unsuitable for our research objectives. For instance, several authors have replicated the methodology developed by Cavalli et al. (2013) and highlighted the indispensability of coupling such automatic approaches with geomorphological analysis

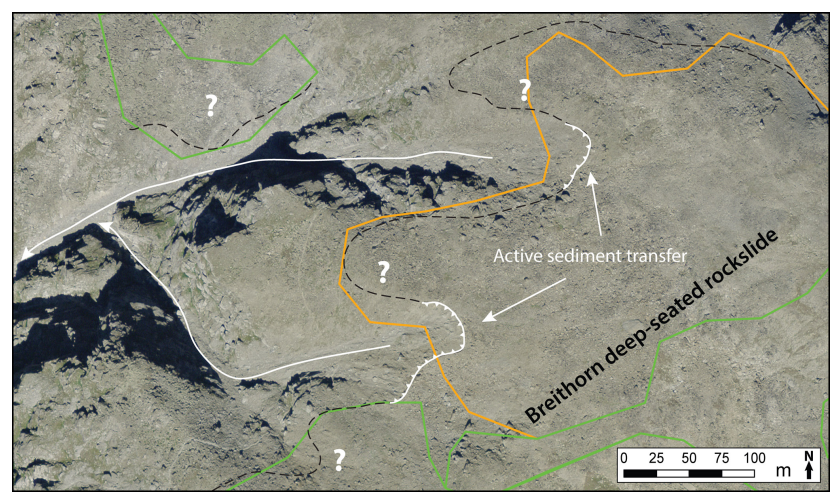

Figure 9. Example of a case of rockslide (Breithorn rockslide, Mattertal) for which the definition of the transit section is rendered difficult by both the length of the landform downslope boundary (black dashed line) and the absence of a clear front. In this example, traces of erosion and transfer are highlighted by the plain white lines while the white question marks indicate locations where sediment transfer could occur but is not clearly evidenced by the images. The colored polygons refer to the areas that were detected as moving in the DInSAR inventory, with the motion generally directed towards the upper left corner.

based on aerial images and in situ field surveys, as relatively frequent discrepancies between computed connectivity index values and field observations were detected (e.g., Messenzehl et al., 2014; Micheletti and Lane, 2016; Tiranti et al., 2018). In addition, these different approaches for automatically inferring connectivity are generally developed at the catchment scale and aim at representing the spatial variability in sediment connectivity. They are therefore not suited to investigate the very local scale, at which the connection between two morphological units typically is. They may also be time consuming to apply at the regional scale, i.e., for a lot of different catchments at once, because they necessitate relatively important computational power. We therefore argue that, despite the interest of such automatic approaches, the methodology developed here is best adapted to the aims of the study. This methodology relies on the analysis of aerial images, which is in any case needed to complement automatic approaches and has the advantage of being easy to apply at the regional scale.

\subsection{Difficulties to define the transit section}

Estimations of sediment transfer rates were obtained using a simple geometrical approach whose application implies some difficulties and uncertainties. For instance, the transit section is not always easy to identify and delimitate. In some cases, especially for rockslides, there is no clear front between the moving landform and the torrential channel. For these landforms, the delimitation of a transit section is based on very uncertain morphological clues observed in the images (e.g., in Fig. 9). In addition, rockslides are treated 
here as if their behavior in terms of sediment transfer is comparable to that of rock glaciers. However, conversely to rock glaciers (Kummert et al., 2018; Kummert and Delaloye, 2018), the potential sedimentary connection between high-altitude rockslides and torrents has never been properly observed and measured. Existing studies focusing on landslides located at lower altitudes (not in periglacial environments) seem to indicate that the connectivity between landslides and fluvial systems is highly variable spatially. For instance, Korup (2005) defines five types of coupling interface (i.e., transit section): area, linear, point, indirect and null. In comparison to rock glaciers, rockslides usually affect entire hillslopes and are characterized by a less concentrated sediment flux, featuring spatially variable flow directions. However, compared to lowlands, high-altitude rockslides share attributes with rock glaciers, as for example a high fraction of coarse debris, at least at the surface, and a kinematical behavior that is influenced by permafrost conditions (Delaloye et al., unpublished data). In terms of sediment yield characteristics, high-altitude rockslides are assumed to behave partly as lowland landslides and partly as permafrost creep landforms. However, deep-seated rockslides have been poorly studied and further investigations would be needed in order to better understand their dynamics and their potential sedimentary connection with torrents.

\subsection{Estimation of the surface velocity}

The determination of the surface velocity rates is also subject to uncertainties. First, no accuracy assessment has been carried out concerning the orthoimages and some deformations and lateral deviations may occur and alter the obtained velocity values. In addition, the manual tracking of boulders on the orthoimages only allows the 2-D velocity to be assessed. These values of $2-\mathrm{D}$ velocity are understandably lower than 3-D values but were used anyway for the estimations of sediment transfer rates, arguing that it would certainly avoid overestimations. As future developments, values of 3-D velocity could be obtained combining $2-\mathrm{D}$ values with the general slope angle that can be extracted for instance from the DEM. More advanced feature tracking procedures based on an image correlation algorithm and coupled with pairs of DEMs can also provide 3-D surface velocities but are more time-consuming. For the large majority of cases, both velocities derived from aerial images and from DInSAR yielded very similar results (Supplement). The differences that remain between the two velocity estimation methods are mainly due to small-scale local variations in surface velocity that could be observed in the images but not in the interferograms. The DInSAR-derived velocity class often represents the displacement rate of the whole landform while the value of surface velocity issued from the analysis of orthophotos is determined at the front, where the velocity might be slightly different than for the rest of the landform (e.g., Fig. 5). In addition, classes of velocity derived for DInSAR data may

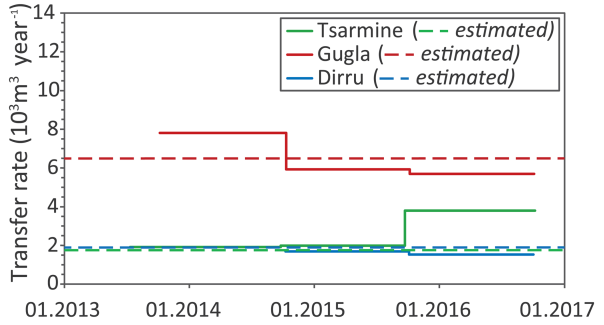

Figure 10. Temporal evolution of lidar-based sediment transfer rates (plain lines) in comparison to values estimated from the approach used in the present paper (dashed lines).

represent slight overestimations as interferograms only cover summer periods and do not account for seasonal changes in velocity rates. For these reasons, velocity values issued for the aerial image analysis were used for the transfer rate estimations, while DInSAR velocity classes were only used as a control. Big differences between values yielded by the two methods were here taken as an indicator of error and led to a reanalysis of the aerial images in order to recalculate velocity values.

In Barboux et al. (2014), the authors mention the possibility of obtaining more detailed classes of deformation rates from the new sets of data used for the update of the inventory (mainly TerraSAR-X, $10 \mathrm{~m}$ resolution, half wavelength $=1.55 \mathrm{~cm}$ ). Such an approach was not applied here but more precise evaluation of velocity rate could theoretically be gained from the available DInSAR interferograms and enhance the confidence over the velocity estimations.

Values of both surface velocities and transit sections contain uncertainties and for these reasons the resulting estimations of sediment transfer rates should be taken as order of magnitudes more than as absolute values. The sediment transfer rates of three rock glaciers present in this inventory, namely Dirru, Gugla and Tsarmine, were calculated from repeated lidar surveys in the frame of previous studies (see Kummert and Delaloye, 2018). Lidar-derived values of annual sediment transfer rates and a comparison with values obtained from the simplified approach used in the present paper are displayed in Fig. 10. The orders of magnitude yielded by these two different studies are similar and indicate that, even if the simplified approach cannot represent temporal variations, it can be used as a good first estimation. Given the aim of the developed methodological framework, such a simplified approach represents a good compromise to quickly obtain reliable orders of magnitude of sediment transfer rates for a relatively large number of landforms. Values of surface velocity used to produce these estimations are however valid for a period spanning from 2007 to 2012 and thus represent a state of activity that may not be representative of current dynamics. Some sites may have encountered a strong destabilization since 2012, or on the contrary, may have slowed down or even deactivated. The inventory thus remains in- 
dicative and further investigations would be needed to assess the current sediment transfer activity characterizing identified sites.

\subsection{Reproducibility of the method}

One of the objectives of the study was to develop an easily reproducible methodology. The same type of problematic most likely occurs in other alpine regions as well as in other mountain ranges and such connectivity assessments could be of interest in other areas. Therefore, the method relies on relatively simple input data: a high-resolution DEM, high-resolution aerial images and an inventory of periglacial moving landforms. The availability of these three datasets is mandatory for the application of the methodology, but not especially in the same format and quality. For instance, the connectivity assessment can be accomplished with lowerresolution DEM and aerial images. In most cases, the second in-depth connectivity check can be performed via detailed geomorphological mapping and should not necessarily rely on the availability of time series of orthoimages. Finally, the key issue is probably the availability of an initial inventory that can be used to localize the periglacial moving landforms in the study region. The inventory does not have to be inferred from SAR interferometry and can be based for instance on field surveys or interpretation of aerial images and DEMs (e.g., Delaloye et Morand, 1997; Lambiel and Reynard, 2003; Kellerer-Pirklbauer et al., 2012; Sattler et al., 2016; Marcer et al., 2017). Though, in the absence of such an inventory, a preparatory step should be undertaken at least to localize the moving landforms in the chosen perimeter of the study. The second step of the methodology, i.e., the estimation of sediment transfer rates between moving landforms and torrents, could be more difficult to apply in data scarce areas as both high-resolution DEM and surface velocity data are needed.

\section{Conclusion}

The methodology developed here aimed to identify torrential catchments in which one or several moving landform(s) located in periglacial environment is(are) connected to the torrential network system at the regional scale. It was designed to be quickly applicable and reproducible and therefore relies on the analysis of relatively basic data (aerial images, DEM). The goal of producing a relatively simple approach asked for several simplifications in both the connectivity assessment, which is basically carried out through visual observation of aerial images, and the estimation of sediment transfer rates. The results are thus indicative and the values of sediment transfer rates produced in this study should be taken as orders of magnitudes rather than as absolute numbers. Nevertheless, the outcomes of the application of this method are valuable as they represent, to our knowledge, the first inventory of moving landforms focusing on sediment connectivity with torrents produced at a regional scale. In general the results showed that in the studied region, the cases of connectivity between periglacial moving landforms and torrents are quite rare $(6 \%$ of all torrents and interfluves and about $8 \%$ of all detected moving landforms). In addition, most of these cases of connectivity (about $70 \%$ ) are characterized by relatively low estimated sediment transfer, below $500 \mathrm{~m}^{3} \mathrm{yr}^{-1}$. However, a few (17\%) of the moving landforms identified as connected to the torrential network system showed quite high sediment transfer rates (above $1000 \mathrm{~m}^{3} \mathrm{yr}^{-1}$ ), indicating that such landforms can in some cases represent significant active sediment sources for the torrents. As the sediment transfer rates are directly related to the rates at which these landforms move, the level of sediment transfer activity may change according to interannual and decadal evolution of surface velocity, which point towards an accelerating behavior in the Alps. The developed methodology and the results yielded are thus essential to highlight the sites where slope movements actively transport sediment into torrents. Such information can then be used to better manage the concerned catchments and to point out the sites where additional investigations such as more specific debris flow hazard assessment or in situ surface velocity monitoring can be launched if judged necessary. We therefore argue that connectivity should be recognized as an important characteristic to be either implemented in future rock glaciers or moving landform inventories, or developed and added in areas where such inventories already exist. By doing so, the primary information about the connectivity is available for potentially more detailed future investigations.

Data availability. A table with the results of this study is published as a Supplement to the article. In addition, these results are available in shapefile format (.shp) upon request.

Supplement. The supplement related to this article is available online at: https://doi.org/10.5194/gh-73-357-2018-supplement.

Author contributions. MK designed the methodological approach under the supervision of RD. MK conducted the analysis, made all the figures and wrote the initial version of the paper. RD improved the paper.

Competing interests. The authors declare that they have no conflict of interest.

Acknowledgements. The authors wish to thank Chloé Barboux for helping with the early stages of the development of the methodology. In addition, acknowledgements go to the editor and the two anonymous referees, who kindly participated in improving the paper. 
Edited by: Christoph Graf

Reviewed by: two anonymous referees

\section{References}

Arenson, L., Hoelzle, M., and Springman, S.: Borehole deformation measurements and internal structure of some rock glaciers in Switzerland, Permafrost Periglac. Process., 13, 117-135, 2002.

Barboux, C., Delaloye, R., and Lambiel, C.: Inventorying slope movements in an Alpine environment using DInSAR, Earth Surf. Proc. Land., 39, 1078-1094, 2014.

Barsch, D.: Permafrost creep and rock glaciers, Permafrost Periglac. Process., 3, 175-188, 1992.

Benn, D. I., Kirkbride, M. P., Owen, L. A., and Brazier, V.: Glaciated valley landsystems, in: Glacial Landsystems, Arnold, London, 372-406, 2003.

Bodin, X., Thibert, E., Fabre, D., Ribolini, A., Schoeneich, P., Francou, B., Reynaud, L., and Fort, M.: Two decades of responses (1986-2006) to climate by the Laurichard rock glacier, French Alps, Permafrost Periglac. Process., 20, 331-344, 2009.

Bosson, J.-B. and Lambiel, C.: Internal structure and current evolution of very small debris-covered glacier systems located in alpine permafrost environments, Front. Earth Sci., 4, 1-17, https://doi.org/10.3389/feart.2016.00039, 2016.

Bovis, M. J. and Jakob, M.: The role of debris supply conditions in predicting debris flow activity, Earth Surf. Proc. Land., 24, 10391054, 1999.

Bracken, L. J., Turnbull, L., Wainwright, J., and Bogaart, P.: Sediment connectivity: a framework for understanding sediment transfer at multiple scales, Earth Surf. Proc. Land., 40, 177-188, 2015.

Buchli, T., Merz, K., Zhou, X., Kinzelbach, W., and Springman, S. M.: Characterization and monitoring of the Furggwanghorn rock glacier, Turtmann Valley, Switzerland: Results from 2010 to 2012, Vadose Zone J., 12, 1-15, https://doi.org/10.2136/vzj2012.0067, 2012.

Cavalli, M., Trevisani, S., Comiti, F., and Marchi, L.: Geomorphometric assessment of spatial sediment connectivity in small Alpine catchments, Geomorphology, 188, 31-41, 2013.

D'Agostino, V. and Marchi, L.: Debris flow magnitude in the Eastern Italian Alps: data collection and analysis, Phys. Chem. Earth Pt. C, 26, 657-663, 2001.

Delaloye, R.: Contribution à l'étude du pergélisol de montagne en zone marginale, in: GeoFocus vol. 10, Thèse, Département de Géosciences/Géographie, Université de Fribourg, Fribourg, 2004.

Delaloye, R. and Morand, S.: Du Val Ferret au Grand-Combin (Alpes Valaisannes): Inventaire des glaciers rocheux et analyse spatiale du pergélisol à l'aide d'un système d'information géographique (IDRISI), MS Thesis, University of Fribourg, Fribourg, Switzerland, 1997.

Delaloye, R., Lambiel, C., Lugon, R., Raetzo, H., and Strozzi, T.: ERS InSAR for detecting slope movement in a periglacial mountain environment (western Valais Alps, Switzerland), in: Proceedings of HMRSC-IX, Grazer Schriften der Geographie und Raumforschung, 43, 113-120, 2007a.

Delaloye, R., Lambiel, C., Lugon, R., Raetzo, H., and Strozzi, T.: Typical ERS InSAR signature of slope movement in a periglacial mountain environment (Swiss Alps), in: Proceedings of ENVISAT Symposium 2007, ESA SP-636, July 2007, 6 pp., 2007 b.

Delaloye, R., Perruchoud, E., Avian, M., Kaufmann, V., Bodin, X., Hausmann, H., I keda, A., Kääb, A., Kellerer-Pirklbauer, A., Krainer, K., Lambiel, C., Mihajlovic, D., Staub, B., Roer, I., and Thibert, E.: Recent interannual variations of rock glacier creep in the European Alps, edited by: Kane, D. L. and Hinkel, K. M., in: Proceedings of the 9th International Conference on Permafrost, 29 June-3 July 2008, Fairbanks, Alaska, 343-348, 2008.

Delaloye, R., Lambiel, C., and Gärtner-Roer, I.: Overview of rock glacier kinematics research in the Swiss Alps. Seasonal rhythm, interannual variations and trends over several decades, Geogr. Helvet., 65, 135-145, 2010.

Delaloye, R., Morard, S., Barboux, C., Abbet, D., Gruber, V., Riedo, M., and Gachet, S.: Rapidly moving rock glaciers in Mattertal, in: Mattertal - ein Tal in Bewegung, Publikation zur Jahrestagung der Schweizerischen Geomorphologischen Gesellschaft, 29 Juni-1 Juli 2011, edited by: Graf, C., Eidg. Forschungsanstalt WSL, St. Niklaus, Birmensdorf, 113-124, 2013.

Fryirs, C.: (Dis)Connectivity in catchment sediment cascades: a fresh look at the sediment delivery problem, Earth Surf. Proc. Land., 38, 30-46, 2013.

Gärtner-Roer, I. and Nyenhuis, M.: Volume estimation, kinematics and sediment transfer rates of active rockglaciers in the Turtmann Valley, Switzerland, in: Landform - structure, evolution, process control, Lecture Notes in Earth Sciences 115, edited by: Otto, J. C. and Dikau, R., Springer, Berlin, Heidelberg, 185-198, 2010.

Haeberli, W.: Creep of mountain permafrost: internal structure and flow of alpine rock glaciers, in: vol. 77, Mitteilungen der Versuchsanstalt für Wasserbau, Hydrologie und Glaziologie der ETH Zürich, Zürich, 1985.

Haeberli, W., Hallet, B., Arenson, L., Elconin, R., Humlum, O., Kääb, A., Kaufmann, V., Ladanyi, B., Matsuoka, N., Springman, S., and Vonder Mühll, D.: Permafrost creep and rock glacier dynamics, Permafrost Periglac. Process., 17, 189-214, 2006.

Harvey, A. M.: Effective timescales of coupling within fluvial systems, Geomorphology, 44, 175-201, 2002.

Heckmann, T. and Schwanghart, W.: Geomorphic coupling and sediment connectivity in an alpine catchment - Exploring sediment cascades using graph theory, Geomorphology, 182, 89-103, 2013.

Humlum, O.: The geomorphic significance of rock glaciers: estimates of rock glacier debris volumes and headwall recession rates in West Greenland, Geomorphology, 35, 41-67, 2000.

Ikeda, A., Matsuoka, N., and Kääb, A.: Fast deformation of perennially frozen debris in a warm rock glacier in the Swiss Alps: An effect of liquid water, J. Geophys. Res., 113, 1-12, https://doi.org/10.1029/2007JF000859, 2008.

Jomelli, V., Brunstein, D., Grancher, D., and Pech, P.: Is the response of hill slope debris flow to recent climate change univocal? A case study in the Massif des Ecrins (French Alps), Climatic Change, 85, 119-137, 2007.

Kääb, A., Frauenfelder, R., and Roer, I.: On the response of rockglacier creep to surface temprature increase, Global Planet. Change, 56, 172-187, 2007.

Kaufmann, V., Ladstädter, R., and Kienast, G.: 10 years of monitoring of the Doesen rock glacier (Ankogel group, Austria) - A review of the research activities for the time period 1995-2005, edited by: Petrovic, D., in: Proceedings of the 5th Mountain Car- 
tography Workshop, March-April 2006, Bohinj, Slovenia, 129144, 2007.

Kellerer-Pirklbauer, A. and Kaufmann, V.: About the relationship between rock glacier velocity and climate parameters in central Austria, Aust. J. Earth Sci., 105, 94-112, 2012.

Kellerer-Pirklbauer, A., Lieb, G. K., and Kleinferchner, H.: A new rock glacier inventory of the eastern European Alps, Aust. J. Earth Sci., 105, 78-93, 2012.

Korup, O.: Geomorphic imprint of landslides on alpine river systems, southwest New Zealand, Earth Surf. Proc. Land., 30, 783800,2005

Kummert, M. and Delaloye, R.: Quantifying sediment transfer between the front of an active alpine rock glacier and a torrential gully, in: Geomorphometry for Geosciences, edited by: Jasiewicz, J., Zwolinski, Z., Mitasova, H., and Hengl, T., Adam Mickiewicz University in Poznan - Institute of Geoecology and Geoinformation, International Society for Geomorphometry, Poznan, 193-196, 2015.

Kummert, M. and Delaloye, R.: Mapping and quantifying sediment transfer between the front of rapidly moving rock glaciers and torrential gullies, Geomorphology, 309, 60-76, 2018.

Kummert, M., Delaloye, R., and Braillard, L.: Erosion and sediment transfer processes at the front of rapidly moving rock glaciers: systematic observations with automatic cameras in the western Swiss Alps, Permafrost Periglac. Process., 29, 21-33, 2018.

Lambiel, C. and Reynard, E.: Cartographie de la distribution du pergélisol et datation des glaciers rocheux dans la région du Mont Gelé (Valais), in: Entwicklungstendenzen und Zukunftsperspektiven in der Geomorphologie, edited by: Maisch, M., Vonder Mühll, D., and Monbaron, M., Geographisches Institut, Physische Geographie, Universität Zürich, Zürich, 91-103, 2003.

Lambiel, C., Delaloye, R., Strozzi, T., Lugon, R., and Raetzo, H.: ERS InSAR for assessing rock glacier activity, edited by: Kane, D. L. and Hinkel, K. M., in: Proceedings of the 9th International Conference on Permafrost, 29 June-3 July 2008, Fairbanks, Alaska, 1019-1025, 2008.

Lexartza-Artza, I. and Wainwright, J.: Hydrological connectivity: Linking concepts with practical implications, Catena, 79, 146$152,2009$.

Lugon, R. and Stoffel, M.: Rock glacier dynamics and magnitudefrequency relations of debris flows in a high-elevation watershed: Ritigraben, Swiss Alps, Global Planet. Change, 73, 202-210, 2010.

Marcer, M., Bodin, X., Brenning, A., Schoeneich, P., Charvet, R., and Gottardi, F.: Permafrost Favorability Index: Spatial Modeling in the French Alps Using a Rock Glacier Inventory, Front. Earth Sci., 5, 1-17, 2017.
Matsuoka, N.: Solifluction rates, processes and landforms: a global review, Earth-Sci. Rev., 55, 107-134, 2001.

Messenzehl, K., Hoffmann, T., and Dikau, R.: Sediment connectivity in the high-alpine valley of Val Müschauns, Swiss National Park - linking geomorphic field mapping with geomorphometric modelling, Geomorphology, 221, 215-229, 2014.

Micheletti, N. and Lane, S. N.: Water yield and sediment export in small, partially glaciated Alpine watersheds in a warming climate, Water Resour. Res., 52, 4924-4943, 2016.

PERMOS: Permafrost in Switzerland 2010/2011 to 2013/2014, edited by: Noetzli, J., Luethi, R., and Staub, B., Glaciological Report (Permafrost) No. 12-15, Cryospheric Commission of the Swiss Academy of Sciences, 85 pp., 2016.

Rebetez, M., Lugon, R., and Baeriswyl, P.-A.: Climatic change and debris flows in high mountain regions: the case study of the Ritigraben torrent (Swiss Alps), Climatic Change, 36, 371-389, 1997.

Rickenmann, D.: Empirical relationships for debris flows, Nat. Hazards, 19, 47-77, 1999.

Roer, I., Kääb, A., and Dikau, R.: Rockglacier acceleration in the Turtmann valley (Swiss Alps): probable controls, Norweg. J. Geogr., 59, 157-163, 2005.

Sattler, K., Keiler, M., Zischg, A., and Schrott, L.: On the connection between debris flow activity and permafrost degradation: a case study from the Schnalstal, south Tyrolean Alps, Italy, Permafrost Periglac. Process., 22, 254-265, 2011.

Sattler, K., Anderson, B., Mackintosh, A., and Norton, K.: Estimating permafrost distribution in the maritime Southern Alps, New Zealand, based on climatic conditions at rock glacier sites, Front. Earth Sci., 4, 1-17, 2016.

Schwab, M., Rieke-Zapp, D., Schneider, H., Liniger, M., and Schlunegger, F.: Landsliding and sediment flux in the Central Swiss Alps: A photogrammetric study of the Schimbrig landslide, Entlebuch, Geomorphology, 97, 392-406, 2008.

Shroder, J. F., Bishop, M. P., Copland, L., and Sloan, V. F.: Debriscovered Glaciers and Rock Glaciers in the Nanga Parbat, Himalaya, Pakistan, Geograf. Ann. A, 82, 17-31, 2000.

Tiranti, D., Crema, S., Cavalli, M., and Deangeli, C.: An Integrated Study to Evaluate Debris Flow Hazard in Alpine Environment, Front. Earth Sci., 6, 1-14, 2018.

Williams, P. J. and Smith, M. W.: The Frozen Earth: Fundamentals of Geocryology, Cambridge University Press, Cambridge, 1989.

Zimmermann, M., Mani, P., and Romang, H.: Magnitude-frequency aspects of alpine debris flows, Eclogae Geologicae Helvetiae, 90, 415-420, 1997. 